\title{
Comparative histology and ontogenetic change in the carapace of armadillos (Mammalia: Dasypodidae)
}

\author{
C. M. Krmpotic ${ }^{1,2} \cdot$ M. R. Ciancio $0^{1,2,3}$ - A. A. Carlini ${ }^{1,2,3}$ - M. C. Castro ${ }^{4}$. \\ A. C. Scarano ${ }^{2,5}$ - C. G. Barbeito ${ }^{1,6}$
}

Received: 8 March 2015/Revised: 30 July 2015 / Accepted: 1 September 2015

(c) Springer-Verlag Berlin Heidelberg 2015

\begin{abstract}
Among extant mammals, the presence of osteoderms is limited to armadillos (Xenarthra, Dasypodidae), being one of its distinctive features. The osteoderms are articulated to form a carapace that covers their body dorsally. In this paper we study the integumentary structures of the armadillos Chaetophractus vellerosus, Chaetophractus villosus, Euphractus sexcinctus, and Zaedyus pichiy (Euphractinae), Dasypus hybridus, and Dasypus novemcinctus (Dasypodinae) within a comparative framework, aiming to identify patterns common to the family and to the subfamilies Dasypodinae and Euphractinae, as well as peculiarities of each species. Differences between the two subfamilies were observed in
\end{abstract}

Communicated by A. Schmidt-Rhaesa.

C. M. Krmpotic

ckrmpotic_pv@fcnym.unlp.edu.ar

1 CONICET, La Plata, Argentina

2 División de Paleontología Vertebrados, Museo de La Plata, Paseo del Bosque s/n, B1900FWA La Plata, Provincia de Buenos Aires, Argentina

3 Cátedra de Anatomía Comparada. Facultad de Ciencias Naturales y Museo, Universidad Nacional de La Plata, 122 y 60 s/n, B1900FWA La Plata, Provincia de Buenos Aires, Argentina

4 Laboratório de Paleontologia de Ribeirão Preto, Faculdade de Filosofia, Ciências e Letras de Ribeirão Preto, Universidade de São Paulo, Av. dos Bandeirantes 3900, Ribeirão Preto, São Paulo 14050-901, Brazil

5 Departamento de Ciencias Ambientales, Universidad Nacional de Avellaneda, España 350, Avellaneda, Provincia de Buenos Aires, Argentina

6 Cátedra de Histología y Embriología, Facultad de Ciencias Veterinarias, Universidad Nacional de La Plata, 118 y $60 \mathrm{~s} / \mathrm{n}$, B1900FWA La Plata, Provincia de Buenos Aires, Argentina the dorsal integument, related to the production of blood cells and the mobility of the carapace. The Euphractinae present more numerous and larger cavities filled with adipose tissue in the osteoderms, as well as more marginal follicles than the Dasypodinae. These provide thermal insulation that could be related to their distribution in cooler climates. The sebaceous glands associated with surface follicles are also more developed in the Euphractinae and could be related to preventing the desiccation of the cornified scales in arid climates.

Keywords Armadillo - Osteoderm · Cornified scales . Histology $\cdot$ Dasypodinae $\cdot$ Euphractinae

\section{Introduction}

The presence of osteoderms is widely spread among craniates (Sire et al. 2009; Vickaryous and Sire 2009), and it is interpreted as a plesiomorphic character of tetrapods. These structures show considerable lineage-specific variability in shape, size, and composition of tissues (Vickaryous and Sire 2009). Within extant amniotes, osteoderms are found in many sauropsids (Moss 1969; Vickaryous and Sire 2009), whereas in mammals their presence is limited to the armadillos (Xenarthra, Dasypodidae), representing one of their key features. Nevertheless, when the xenarthran fossil record is taken into account, osteoderms are not exclusive to dasypodids; rather, they characterize the clade Cingulata (which also includes glyptodonts and pampatheres) and they are also present (although reduced to simple nodular bones lacking sutures or figures) in some extinct Tardigrada (e.g., Mylodon, Glossotherium).

The osteoderms of Dasypodidae articulate with each other to form a dorsal protective carapace. This covering is 
divided into a cephalic shield (which covers the dorsum of the head), a dorsal shield (covering the trunk), and a caudal sheath (enclosing the tail), except in Cabassous, which lacks the latter (Wetzel et al. 2007). The dorsal shield is subdivided into a scapular buckler, a region of movable bands, and a pelvic buckler (e.g., Scillato-Yané 1982; Krmpotic et al. 2009; Ciancio et al. 2013) (Fig. 1). In addition to this dorsal covering, osteoderms may also be scattered within the integument of the rostrum, the ventral part of the trunk, and the dorsum of the limbs, although not forming continuous shields in those areas.

Osteoderms are externally covered by epidermal cornified scales, and their relation is variable, in particular the degree to which the scales and underlying osteoderms overlap or are coincident (Ciancio and Carlini 2008; Carlini et al. 2009). The cornified scales show pyknotic nuclei and are always linked to an underlying parakeratotic epidermis (Krmpotic et al. 2014). The follicles of the scarce dorsal hairs lie within the osteoderm and emerge from foramina (external surface foramina and piliferous foramina), either piercing the cornified scales through small perforations or passing through the interstices between them (Scillato-Yané 1982; Krmpotic et al. 2009).

Complex glandular structures associated with hair follicles, cornified scales, and osteoderms coexist within the integument of armadillos. Histologically, these osteoderms contain compact bone tissue with primary and secondary osteons (Vickaryous and Hall 2006); concentric osseous lamellae surround large cavities that enclose mainly adipose tissue (yellow bone marrow), hair follicles, sweat glands, and sebaceous glands (Fernández 1931; Hill 2006; Krmpotic et al. 2009). Elements of red bone marrow have also been identified within those cavities (Weiss and Wislocki 1956; Hill 2006; Krmpotic et al. 2009). Although the pattern described is common to the osteoderms of Dasypodidae, noticeable differences in the histological conformation of the dorsal integument have been found between Dasypus sp. (Dasypodinae) and Chaetophractus villosus (Euphractinae) (Ciancio et al. 2007; Krmpotic

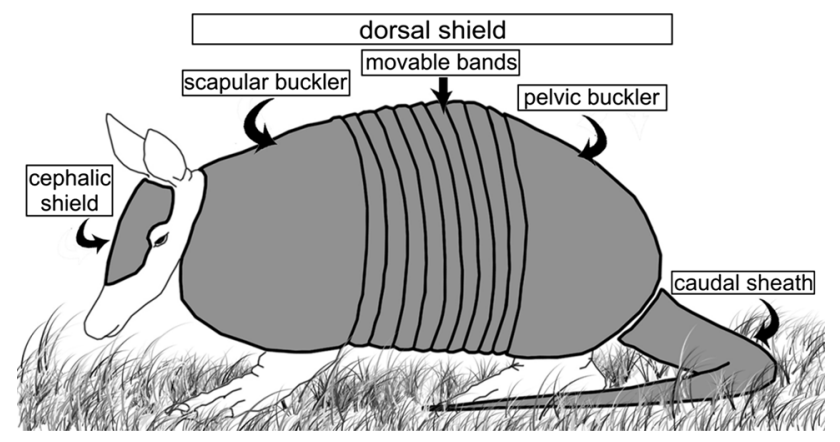

Fig. 1 Caparace. Line drawing of an adult of Dasypus novemcinctus showing the different portions of the carapace et al. 2009). Wolf et al. (2012) pointed out differences in the osteoderm structure between both subfamilies, but they only analyzed dry osteoderms, and did not provide detailed descriptions of histological sections.

Recently, Krmpotic et al. (2012) described the integument and postcranial skeleton of Dasypus hybridus and Chaetopractus vellerosus neonates. At this stage, the integumentary structures and postcranial skeleton differ in their timing of developmental maturity, which might be linked to different life-history strategies.

In this work, we describe the histology of the integument of six species from the two most diverse groups of extant Dasypodidae (Euphractinae and Dasypodinae) in a comparative context. Both groups possess different geographic distribution: the Dasypodinae are related to moist tropical and subtropical environments, whereas the distribution of Euphractinae extends to colder and drier temperate zones (Fig. 2).

The aim of this paper is to provide new comparative data on the conformation of integumentary structures (e.g., epidermis, dermis, osteoderms, red and yellow bone marrow, glandular and nervous tissues) in six species of Dasypodidae and to identify patterns that are common to the family and to each subfamily, as well as distinctive features of each species. In addition, and following the results of Krmpotic et al. (2012), we analyze integumentary changes in relation to homologous structures of neonates.

Moreover, until now the internal anatomy of osteoderms was addressed only through histological studies, which limit the description to the dimension of the cutting plane. In this paper the histological interpretations were reinforced with a full three-dimensional reconstruction of osteoderms based on micro-CT scanning. Finally, we assess the value of these integumentary features as phylogenetic characters and their potential as ecomorphological indicators.

\section{Materials and methods}

Integumentary samples for light microscopy analyses were taken from adults of the following Dasypodidae specimens: Chaetophractus vellerosus AAC 208, Chaetophractus villosus AAC 210, Euphractus sexcinctus AAC 212, and Zaedyus pichiy AAC 209 (Euphractinae), Dasypus hybridus AAC 205, and Dasypus novemcinctus AAC 213 (Dasypodinae). Euphractus sexcinctus and Dasypus novemcinctus were found killed on the road. The remaining specimens were obtained from farmers who hunt these species in their fields because they are considered harmful to agricultural practices, and kept for us to study (farmers record the capture and death dates). Samples were fixed in $5 \%$ formaldehyde and preserved in $70 \%$ ethanol. Small 
Fig. 2 Maps of South America showing the current distribution of the species of Dasypodidae mentioned in the text. a Distribution map of the Dasypodinae species.

b Distribution map of the Euphractinae species. The maps are based on Wetzel (1985) and Aguiar and Fonseca (2008). The arrow indicates that the current distribution of D. novemcinctus includes Central and North America
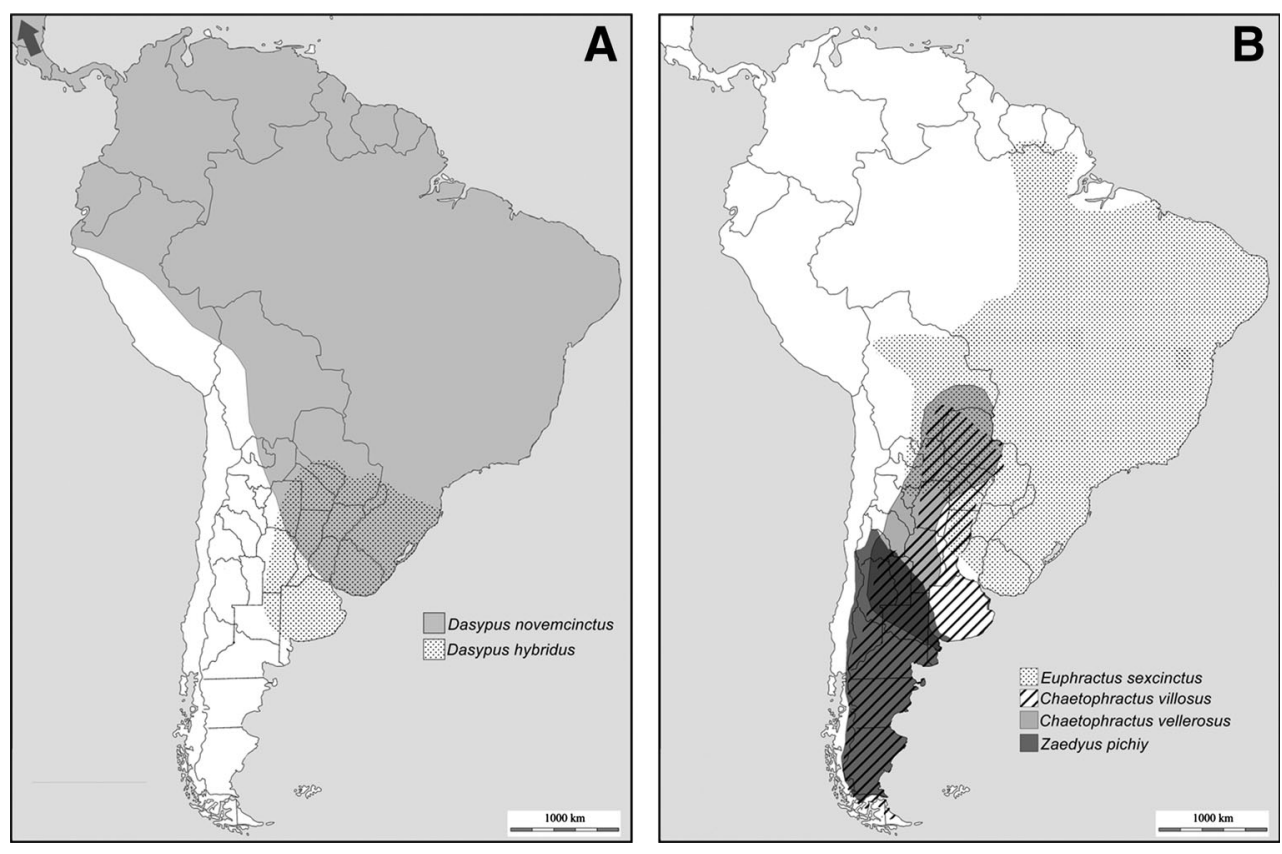

portions $\left(25-30 \mathrm{~mm}^{2}\right)$ of the cephalic shield and different regions of medial zone of the dorsal carapace (scapular and pelvic buckler and movable bands) were taken from each specimen (three samples per zone). The specimens are housed in the Division of Vertebrate Paleontology at the Museo de La Plata. A $10 \%$ formic acid solution was used to decalcify ossifications. Subsequently, the tissues were dehydrated using progressive concentrations of ethanol, from 70 to $100 \%$, and embedded in paraffin. More than 100 serial histological 5- $\mu \mathrm{m}$-thick sections were made per region of each specimen, parallel to the sagittal plane of the osteoderm. Serial sectioning allows a more reliable interpretation of the integumentary structures. Sections were stained using hematoxylin and eosin (H\&E staining), Masson Trichrome, PAS and orcein techniques. All the histological techniques were realized following the protocols described in Bancroft and Stevens (1990).

The 3D reconstructions were performed using Nrecon software v. 1.6.9.8. The digital radiographic images were acquired on a SkyScan 1173 micro-CT with a interslice distance of $40 \mu \mathrm{m}$.

AAC, Colección de la División de Paleontología Vertebrados del Museo de La Plata, La Plata, Argentina.

\section{Terminology}

Some terms concerning the osteoderms and associated integumentary structures are adopted in this paper following Krmpotic et al. (2009, 2012). They are described below and depicted in Fig. 3.

Marginal piliferous follicles (mf): large follicles present along the margins of osteoderms.
Surface piliferous follicles (sf): small follicles related to the external surface foramina of osteoderms.

External surface foramina (esf): foramina located on the external surface, connected to glandular cavities and through which sf emerge.

Piliferous foramina (pf): foramina present on the margins of the osteoderm through which mf emerge.

Two portions are recognized in the osteoderms of the movable bands (or movable osteoderms): a cranial (or not exposed) portion, which is overlapped by the caudal portion of an osteoderm located anteriorly, and a caudal (or exposed) portion, which overlaps the cranial portion of an osteoderm located posteriorly (Fig. 3). The differentiated portion located between the cranial and caudal portions of the osteoderm is termed transverse depression (Krmpotic et al. 2009) or transition zone (Ciancio et al. 2013).

\section{Results}

\section{General patterns for the dorsal integument of Dasypodidae}

The dorsal integument of Dasypodidae exhibits thick cornified scales that cover the whole external surface of the buckler osteoderms, as well as the caudal portion of the movable osteoderms (Fig. 4a, b). In H\&E-stained sections, the cornified scales show an intense ocher-yellowish color, with pyknotic nuclei (Fig. 4c-i). The epidermis underneath the cornified scales lacks a stratum granulosum and is composed only by a stratum basale and one or two layers of stratum spinosum (Fig. $4 \mathrm{~d}-\mathrm{i}$ ). A thin layer of dermis formed 


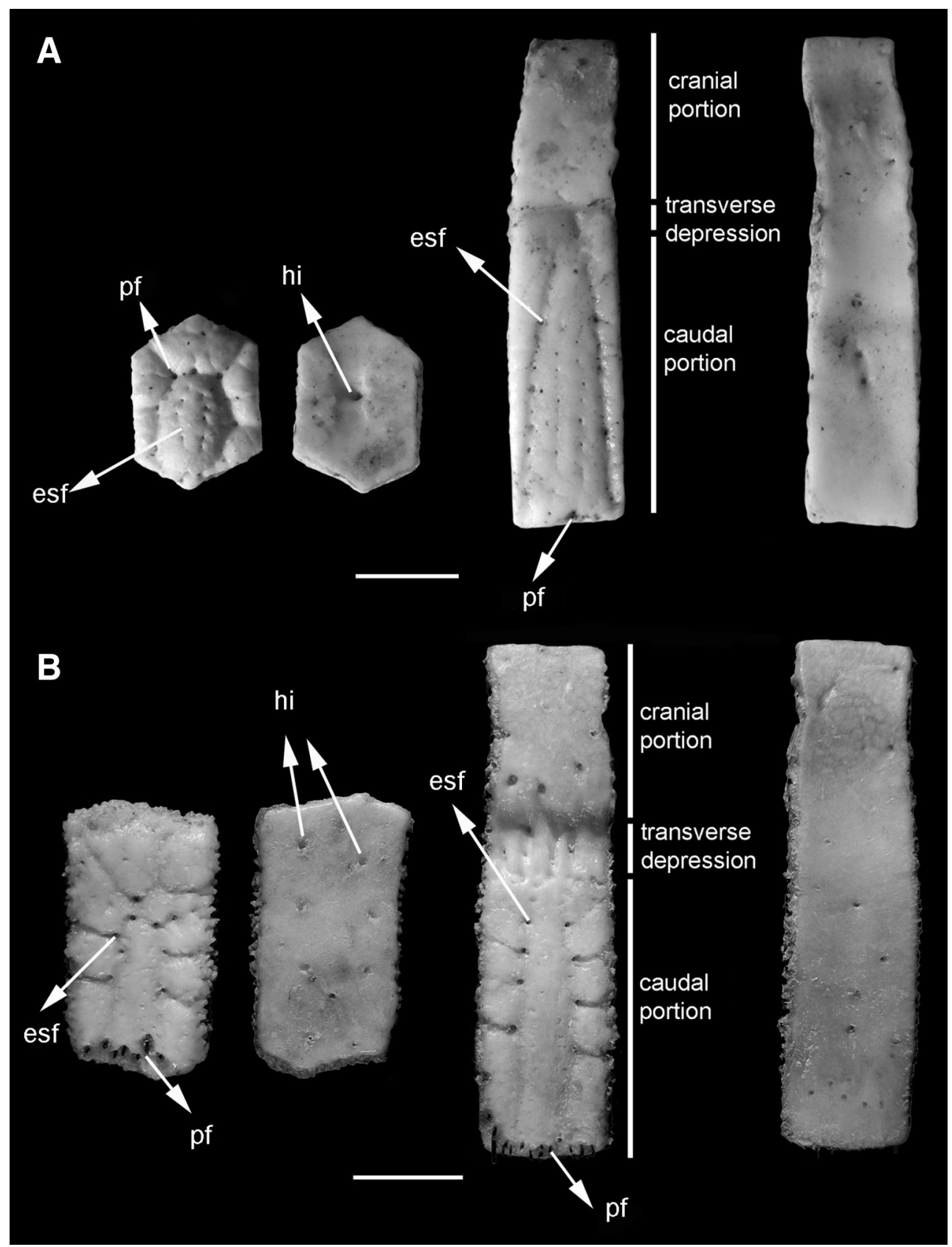

Fig. 3 External morphology of osteoderms. Buckler and movable osteoderms of the dorsal shield of dasypodids. a Osteoderms of Dasypus hybridus (Dasypodinae). b Osteoderms of Chaetophractus villosus (Euphractinae). The osteoderms are showed in external and

by loose connective tissue is observed between the basal lamina of the epidermis and the osteoderm (Fig. 4d-i). The osteoderms occupy almost the entire thickness of the dermis, with either hypodermis or muscular tissue (panniculus carnosus) as the underlying tissue, depending on the species and on the region of the carapace (Fig. 5a-i). internal side views. esf external surface foramina, $h i$ neurovascular ingressions of hypodermis, $p f$ piliferous follicle foramina. Scale bar $5 \mathrm{~mm}$

The buckler osteoderms of adult specimens show an external layer of non-Haversian compact bone (consisting of bone tissue without cavities and with no concentric lamellae forming Haversian systems, see Fig. 6a, b), a middle layer with primary and secondary osteons (Figs. 6a, c, 7a-d), with concentric lamellae encircling large cavities, 

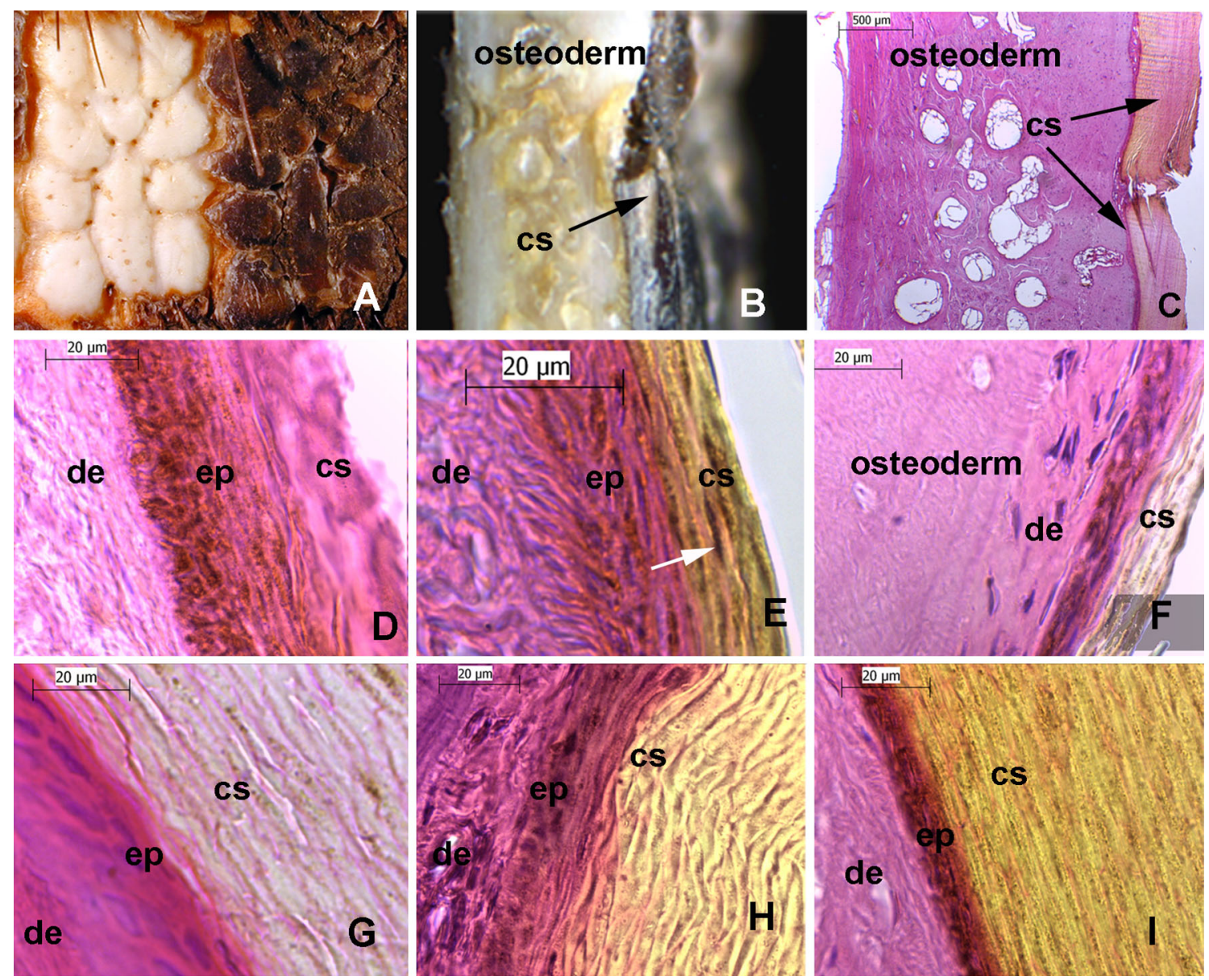

Fig. 4 Cornified scales of the dorsal integument of Dasypodidae. a On the left, buckler osteoderm of Chaetophractus villosus with cornified scales removed; on the right osteoderm covered by cornified scales. b Lateral view of osteoderm with overlying cornified scales. c Osteoderm and cornified scale of C. villosus, H\&E stain. d-

and an internal layer of non-Haversian compact bone (Fig. 6a-d). The latter is composed of collagen bundles that run parallel to the surface, with aligned osteocytes among them, and intersecting each other in various directions (Fig. 6d). The cavities of the middle layer enclose adipose tissue (yellow bone marrow) and sweat glands; the latter are generally associated with sebaceous glands of variable development and, in most species, with surface piliferous follicles of hairs that emerge through the external surface foramina (Fig. 6a). In cavities occupied by both glandular types, each gland has its own duct, but they emerge externally through a single canal (Fig. 6a). In the posterior portion of the osteoderm, the marginal follicles are observed in their respective cavities; these follicles may be associated with sweat and sebaceous glands, or only to sebaceous glands, and are always surrounded by loose connective tissue (Fig. 6a). Laterally, Sharpey fiber bone connects the osteoderms to each other; they represent the i Epidermis and cornified scales, H\&E stain. d Zaedyus pichiy. e $C$. villosus. f Chaetophractus vellerosus. g Euphractus sexcinctus. h Dasypus hybridus. i Dasypus novemcintus. cs cornified scales, de dermis, ep epidermis. White arrows point pyknotic nuclei

direct insertion of soft connective tissue into bone (see Hill 2006 and references therein; Fig. 6a).

The exposed portion of the movable osteoderms shows the same features as described for the buckler osteoderms. Nevertheless, in the cranial (not exposed) portion, the middle layer occupies almost the entire thickness of the osteoderm, whereas the external and the internal layers are extremely thin and formed by non-Haversian bone tissue (Fig. 8a, b). In the middle layer, concentric lamellae surround large cavities filled with yellow or red bone marrow (Fig. 8a, b).

Additionally, dermal ingressions of varied complexity pass through the osteoderm from the underlying dermis to the basal lamina of the epidermis; neurovascular bundles from the hypodermis vary in number and complexity among the species under study (Fig. 5e, i). Nerves are also observed underneath the osteoderms, within the hypodermis (Fig. 5i). 

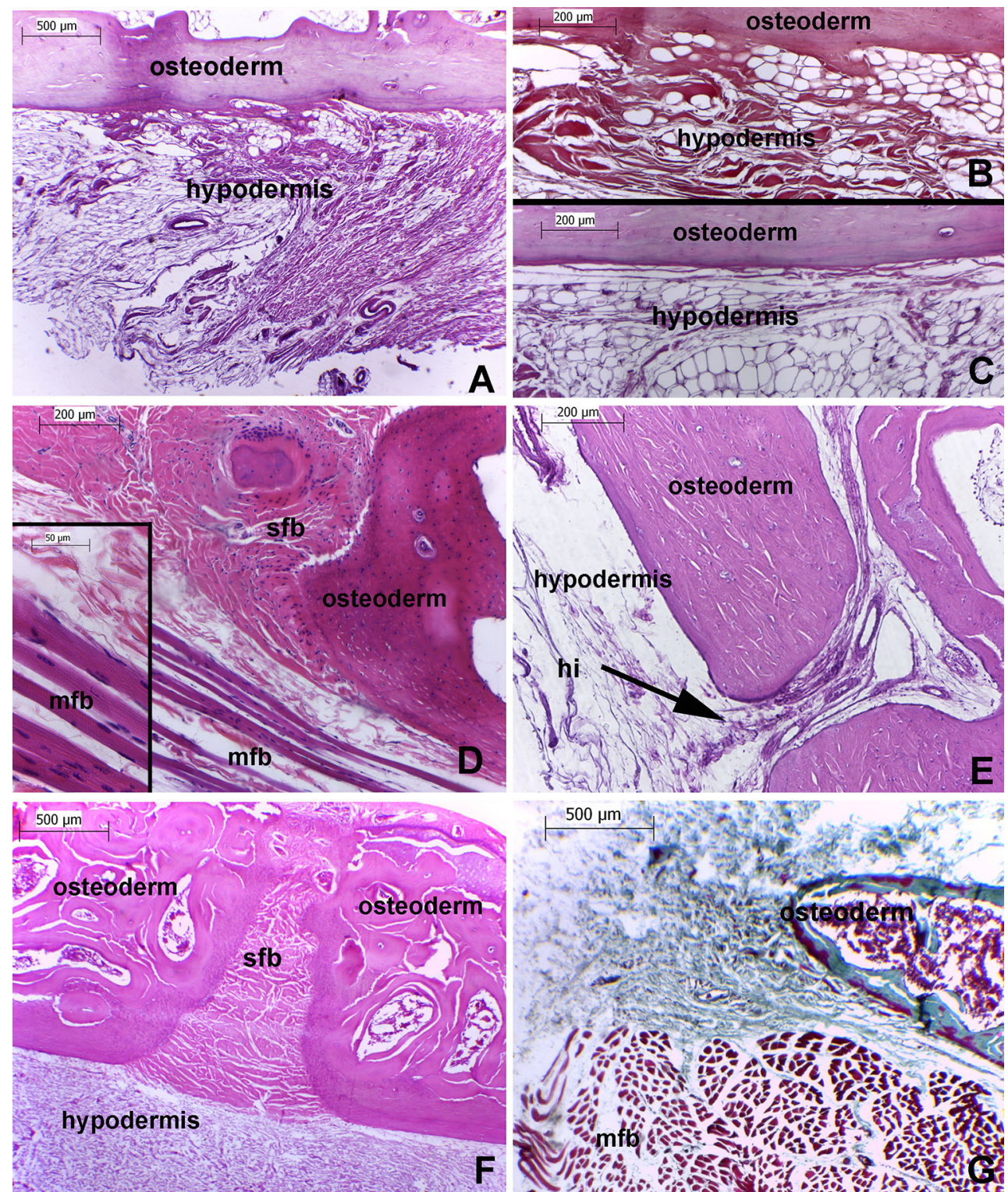

$\mathbf{F}$
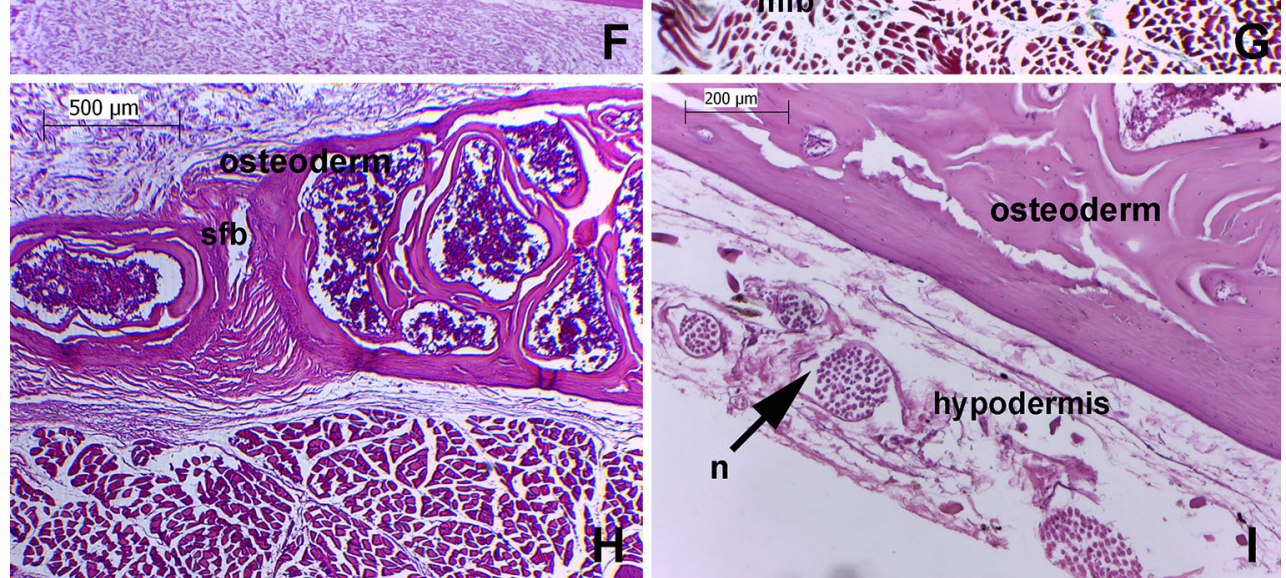

Fig. 5 Hypodermis and panniculus carnosus. a-c Buckler osteoderm and hypodermis of Chaetophractus villosus. a PAS stain. b Orcein stain. c H\&E stain. d Osteoderm and panniculus carnosus of Chaetophractus vellerosus, H\&E stain. e Buckler osteoderm of Zaedyus pichiy showing neurovascular ingression. f-i Dasypus hybridus. f Buckler osteoderm and hypodermis, H\&E stain. g-

h Movable ostoderm and panniculus carnosus. g Trichromic stain, staining striated muscle fibers in red and collagen fibers in green. h H\&E stain. i Movable osteoderm and hypodermis with nerves, which run transversely, deep to adjacent osteoderm, H\&E stain. $h i$ neurovascular ingressions of hypodermis, $m f b$ muscle fibers, $n$ nerves, $s f b$ Sharpey fiber bone 


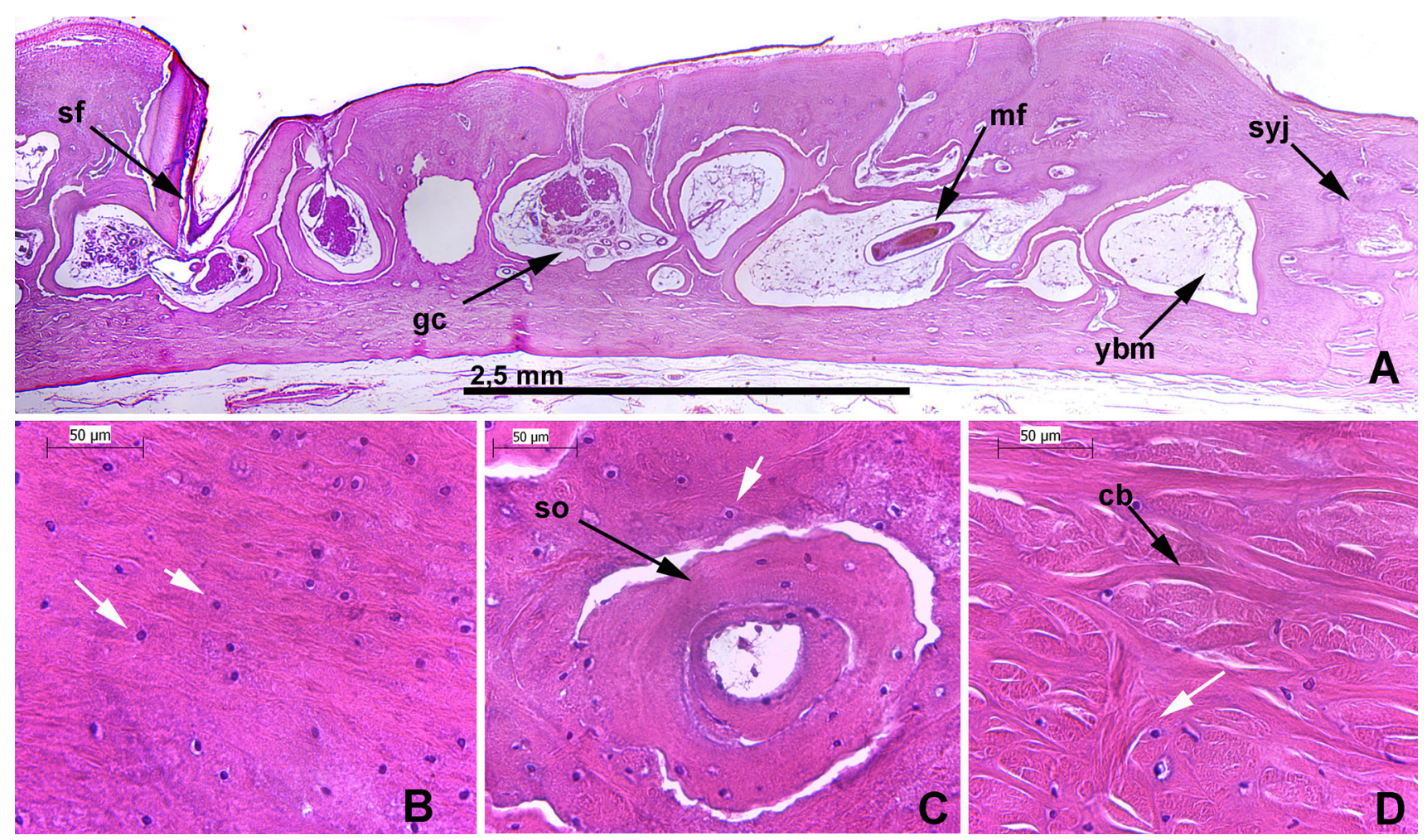

Fig. 6 Buckler osteoderm of Zaedyus pichiy, H\&E stain. a General view. b External layer with non-Haversian compact bone. c Middle layer with secondary osteons. d Internal layer with non-Haversian compact bone. $g c$ gland cavity, $c b$ collagen bundles, $m f$ marginal

\section{General patterns for Euphractinae and species- specific peculiarities}

The osteoderms of Euphractinae are connected to each other by a fibrous joint (syndesmosis), with Sharpey fiber bone and bone indentations (Fig. 9a).

The middle layer of the osteoderm is always well developed and encloses large sebaceous and sweat glands that share the same bone cavity; these glands are generally associated with a surface piliferous follicle (Figs. 6a, 10af). In C. villosus, a single surface piliferous follicle associated with those glands was observed in one buckler osteoderm, whereas glands and follicles were not associated with the remaining buckler osteoderms. Large cavities occupied mainly by sweat glands are present in the cephalic shield osteoderms of C. villosus, whereas the sebaceous glands are poorly developed (Fig. 10e). Blood cell-producing tissue (red bone marrow) was not observed in any portion of the dorsal shield, not even in the large cavities of the cranial (not exposed) portion of the movable osteoderms (Fig. 8b). Nevertheless, red bone marrow was found in the osteoderms of the cephalic shield of $C$. villosus and in few cavities of pelvic buckler osteoderms of $Z$. pichiy (Fig. 11c, d). The Euphractinae possess large piliferous follicle, $s f$ surface piliferous follicles, so secondary osteon, syj syndesmosis joint between two osteoderms, ybm yellow bone marrow. White arrows point osteocytes

cavities for marginal piliferous follicles that also contain great amounts of loose connective tissue (Figs. 6a, 12a, d). Those follicles are associated with poorly developed sebaceous glands (Fig. 12e, f). In C. villosus and $C$. vellerosus, in large areas the glandular cavities and piliferous follicle cavities are continuous with the underlying hypodermis and not separated from the latter by bone tissue (Fig. 12b).

A peculiarity within the movable osteoderms of $C$. vellerosus was an area where the bone tissue was interrupted and the space was occupied by fibrous tissue with Sharpey fiber bone (Fig. 5d). This arrangement inside the osteoderm resembles a fibrous joint and is located between the anterior-most part of the cranial portion and the rest of this portion (Fig. 5d).

The three-dimensional reconstructions of buckler osteoderms of $C$. villosus allow to correctly interpreting the morphology of distinct cavities inside the osteoderm, as well as the relationships among them. The glands associated with surface piliferous follicles are well developed and have a rounded morphology, very different from the large tubular cavities of the marginal piliferous follicles. Glandular cavities are connected with neurovascular ingressions from the hypodermis, and only the most caudal glandular 

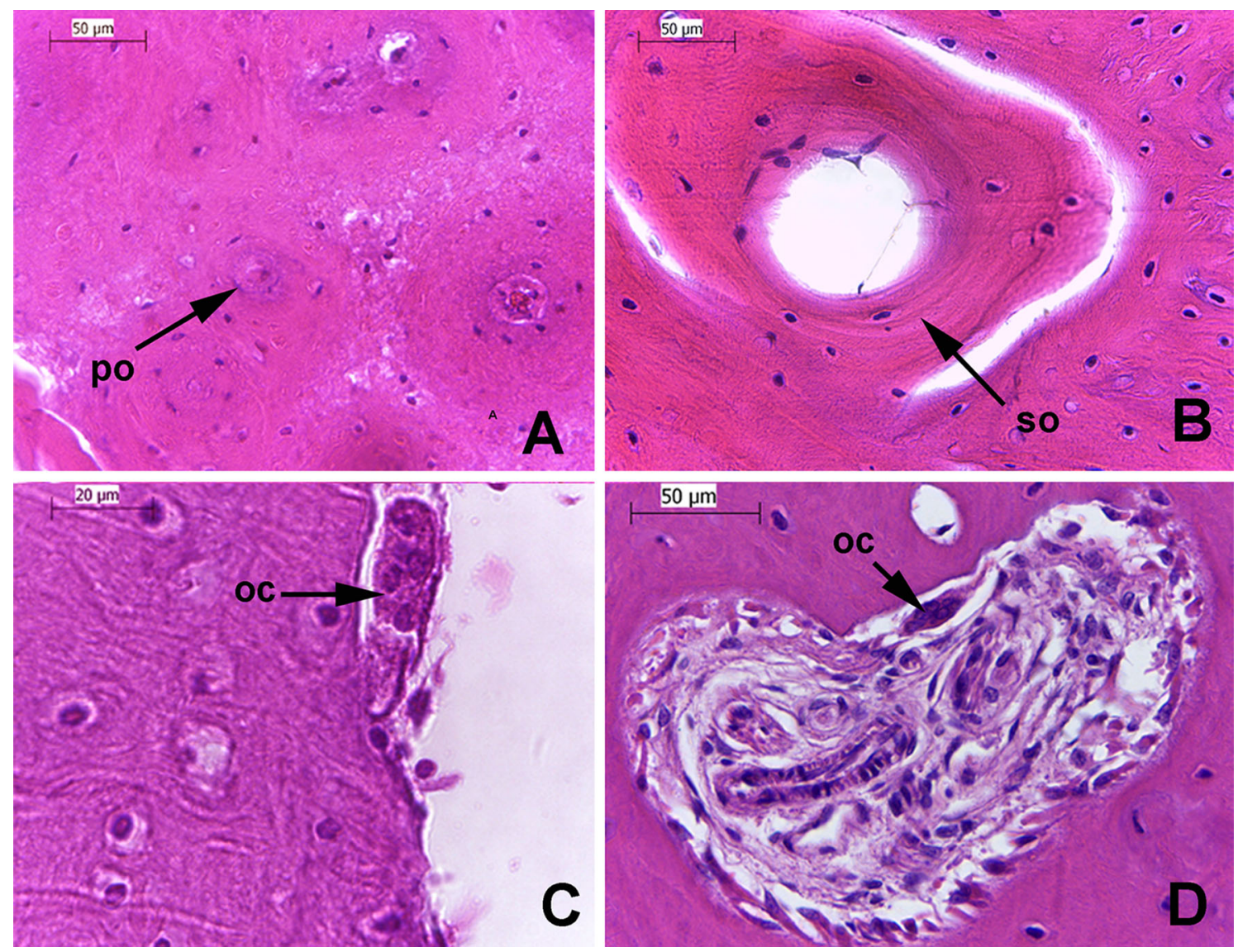

Fig. 7 Osteons. a Primary osteon of Chaetophractus villosus, H\&E stain. b Secondary osteon of Chaetophractus vellerosus, H\&E stain. c Osteoclasts into the secondary osteon of Zaedyus pichiy, H\&E stain.

d Osteoclasts into the secondary osteon of C. vellerosus, H\&E stain. oc osteoclasts, po primary osteon, so secondary osteon

cavities are communicated with the cavities of the marginal piliferous follicle. Likewise, the great development of cavities occupied with yellow bone marrow is noteworthy (Fig. 13a).

\section{General patterns for Dasypodinae and species-specific peculiarities}

In contrast to the condition found in the Euphractinae, the fibrous joints between the osteoderms of Dasypodinae correspond to a typical syndesmosis, with very small bone projections (only at the most surface contacts) and Sharpey fiber bone (Fig. 9b).

The glandular cavities always bear well-developed sweat glands, whereas the sebaceous glands may be either absent or poorly developed, and limited to the dorsal portion of the cavity; surface piliferous follicles are always associated with sweat glands (Fig. 10g, i). Red bone marrow was observed in the movable osteoderms of $D$. hybridus, both in the cavities of the cranial portion and in those of the exposed portion, as well as in some cavities of the buckler osteoderms (Figs. 8a, 11g, k). On the other

hand, only yellow bone marrow was identified in the osteoderms of $D$. novemcinctus, while red bone marrow was absent (Fig. 11j, 1). Yellow bone marrow cavities were also identified in buckler osteoderms (Fig. 11h, i). The movable osteoderms of $D$. hybridus presented discontinuities that may be considered as additional internal joints formed exclusively by Sharpey fiber bone, one at the anterior-most part of the cranial portion and the other between that portion and the caudal one (Fig. 8a). The marginal follicles were always associated with sweat glands (Fig. 12g, i).

The three-dimensional reconstructions of buckler osteoderms of D. hybridus showed that the cavities associated with surface and marginal piliferous follicles are interconnected with each other, have a similar morphology, and also are connected with a unique neurovascular ingression from the hypodermis. The marginal piliferous follicles are larger than the surface piliferous follicles. Both chambers show a lesser development than their counterparts in the Euphractinae. The cavities occupied by yellow bone marrow (or red bone marrow) are also less developed than in the Euphractinae (Fig. 13b). 

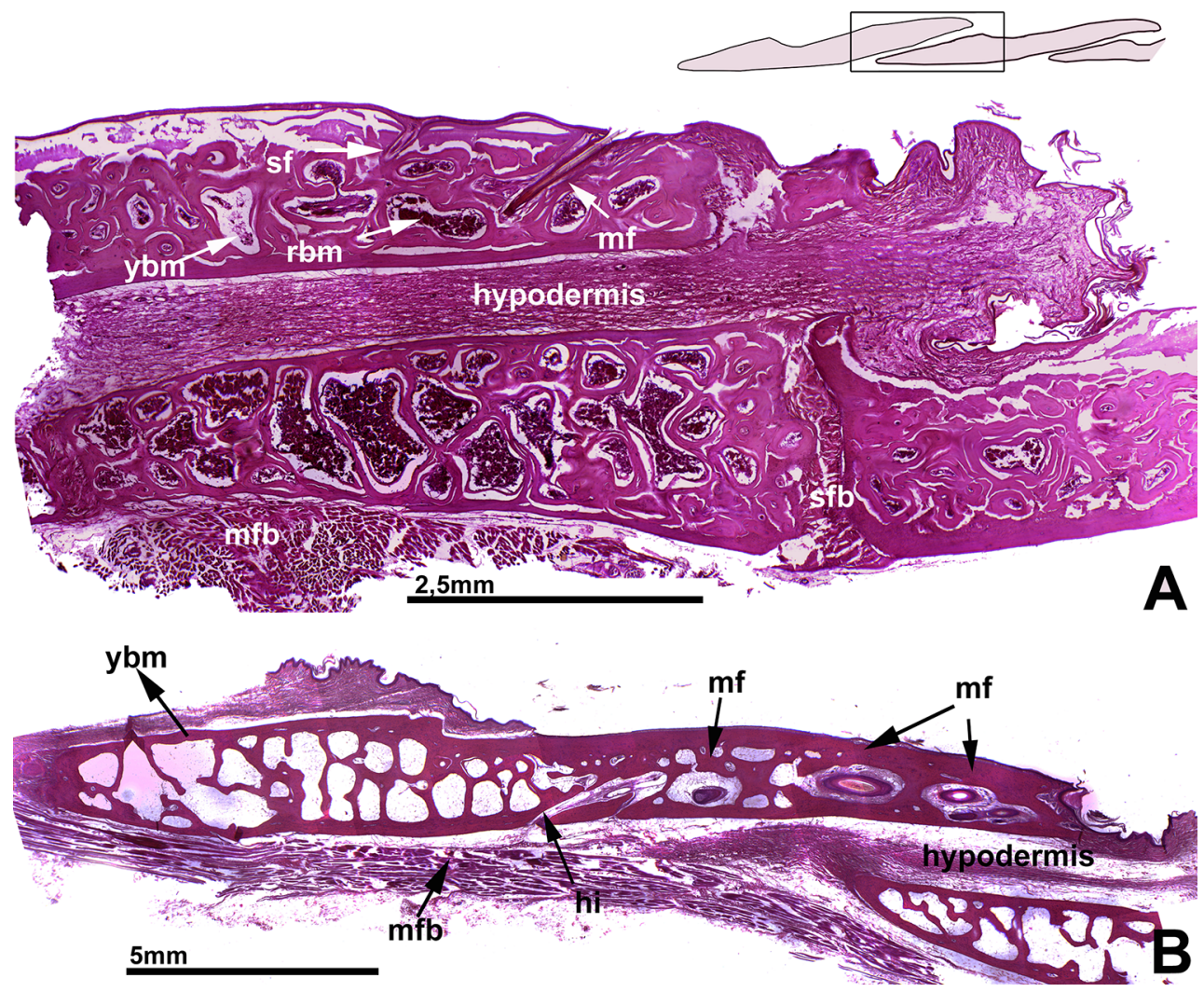

Fig. 8 Movable osteoderms. a Two overlapped osteoderms of movable bands of Dasypus hybridus, H\&E stain. b Two overlapped osteoderms of movable bands of Chaetophractus vellerosus, $\mathrm{H} \& \mathrm{E}$ stain. $h i$ neurovascular ingressions of hypodermis, $m f$ marginal piliferous follicle, $m f b$ muscle fibers, $r b m$ red bone marrow, $s f$ surface piliferous follicles, $s f b$ Sharpey fiber bone, $y b m$ yellow bone marrow
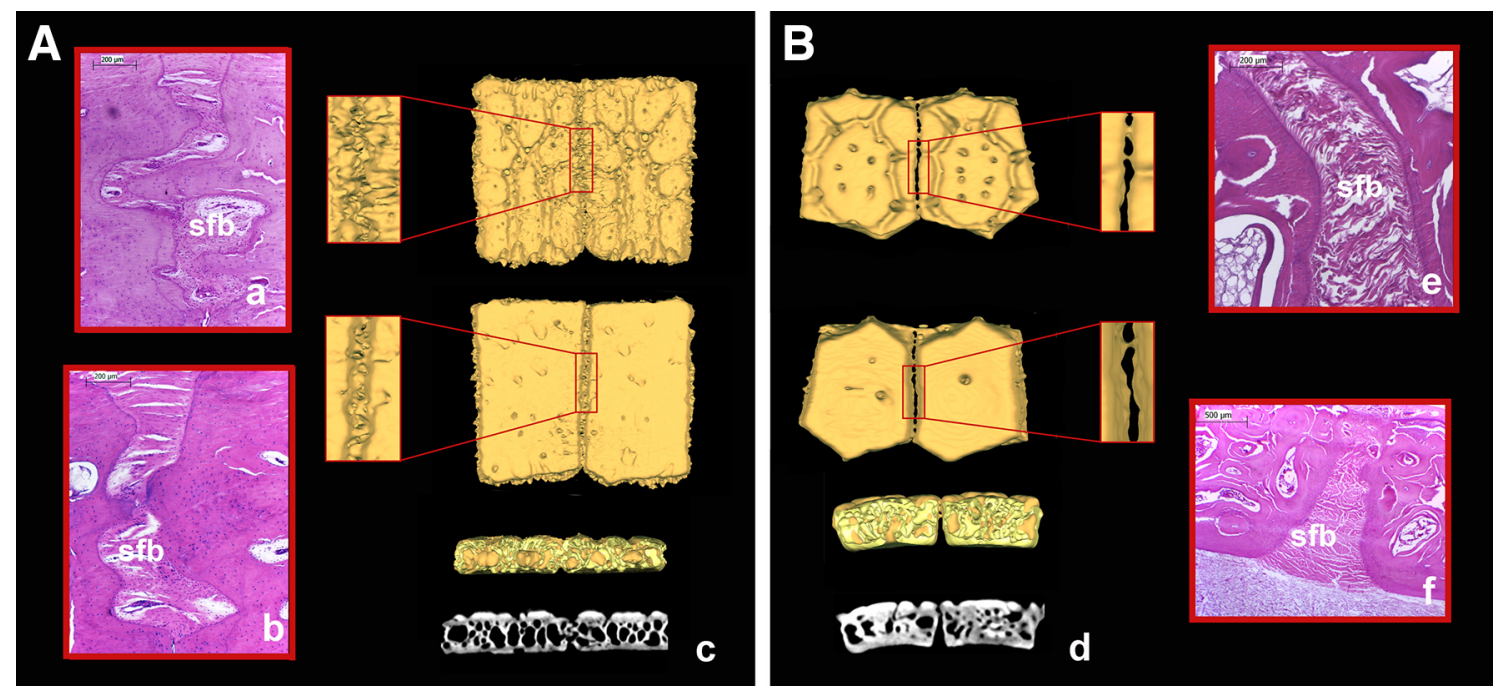

Fig. 9 Connections between adjacent osteoderms. a Chaetophractus villosus, $a, b$ histological details, H\&E stain, $c$ 3D reconstructions and microtomography. b Dasypus hybridus, $d$ 3D reconstructions and microtomography; $f-g$ histological details, H\&E stain. $s f b$ Sharpey fiber bone 

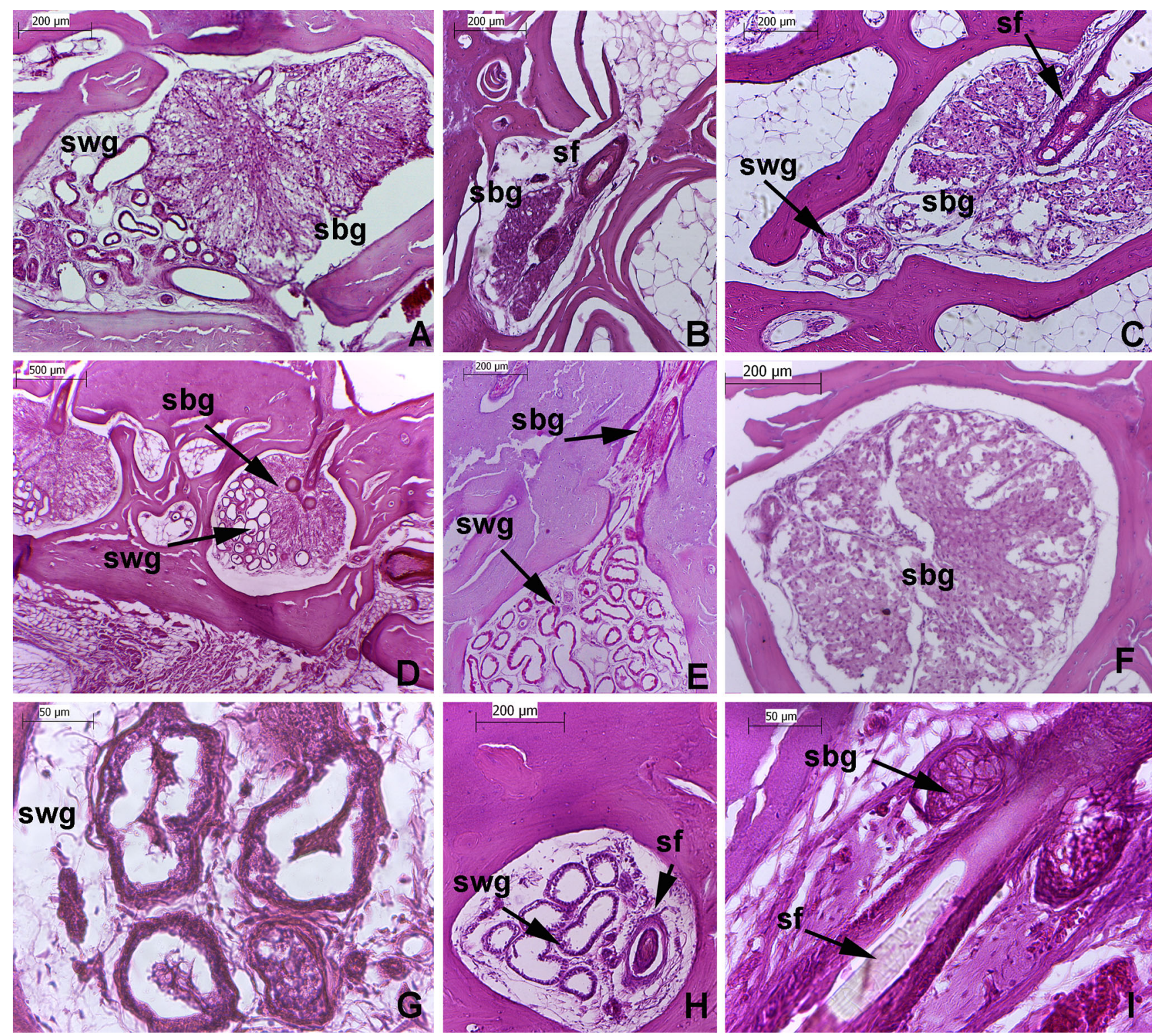

Fig. 10 Glandular cavities and surface piliferous follicle. a Sweat and sebaceous glands of Zaedyus pichiy, H\&E stain. b Surface piliferous follicles with sebaceous gland of Z pichiy, H\&E stain. c Sebaceous and sweat glands associated with surface piliferous follicles of Chaetophractus vellerosus, H\&E stain. d Sweat and sebaceous glands of Chaetophractus villosus, PAS stain. e Sweat and sebaceous glands of $C$. villosus cephalic osteoderm, H\&E stain.

\section{Discussion}

The cornified scales in the studied Dasypodidae present pyknotic nuclei, typical of a parakeratotic cornification; the epidermis underlying these scales is extremely thin and lacks a stratum granulosum. In a previous paper (Krmpotic et al. 2014) the absence of a stratum granulosum under the cornified scales was described for adult specimens of $D$. hybridus, D. novemcinctus, E. sexcinctus, C. villosus, and f Sebaceous gland of Euphractus sexcinctus, H\&E stain. g Sweat gland of Dasypus novemcinctus, H\&E stain. h Sweat glands associated with surface piliferous follicles of Dasypus hybridus, H\&E stain. i Surface piliferous follicles with sebaceous gland of $D$. hybridus, H\&E stain. sbg sebaceous gland, $s f$ surface piliferous follicle, swg sweat gland

C. vellerosus. In this work we observed the same in $Z$. pichiy, leading to the assumption that it represents a characteristic of Dasypodidae, in opposition to the suggestions of Fernández (1931) and Spearman (1966). The latter author considered (erroneously, as demonstrated by Krmpotic et al. 2014) that the cornified scales of Dasypodidae develop without the loss of a stratum granulosum, and this peculiarity was assumed to be a primitive character of the family. However, in neonates (which have not 

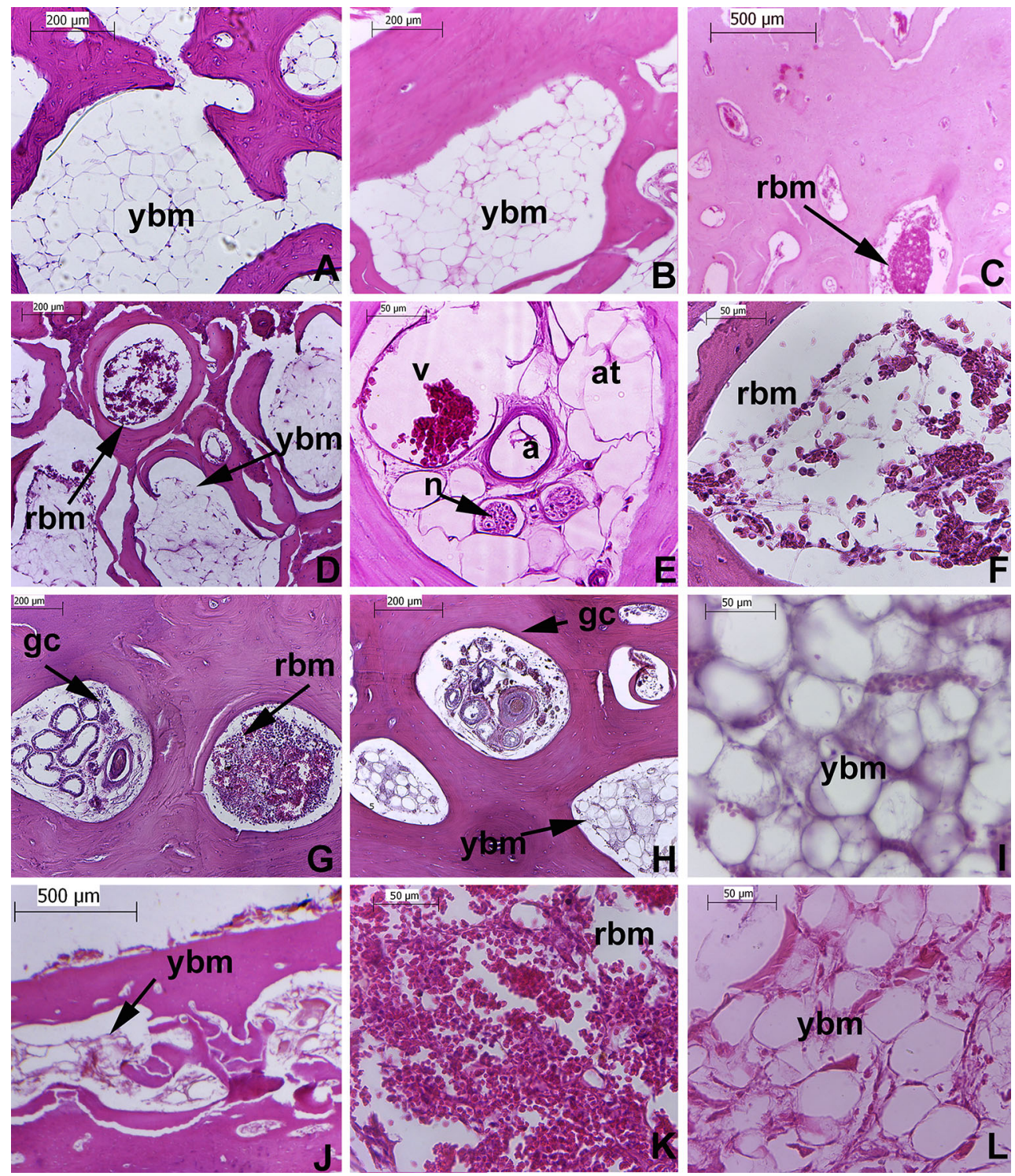

Fig. 11 Red and yellow bone marrow. a Chaetophractus vellerosus, H\&E stain. b Euphractus sexcinctus, H\&E stain. c Chaetophractus villosus, $\mathrm{H} \& \mathrm{E}$ stain. d Zaedyus pichiy, $\mathrm{H} \& \mathrm{E}$ stain. e $C$. villosus, $\mathrm{H} \& \mathrm{E}$ stain. f Z. pichiy, H\&E stain. g-i Dasypus hybridus, $\mathrm{H} \& \mathrm{E}$ stain.

developed cornified scales yet) of C. villosus, C. vellerosus, and $D$. hybridus, a conspicuous stratum granulosum is observed (Krmpotic et al. 2012, 2014). The lack of a stratum granulosum in the integumentary regions with cornified scales seems to be a common feature among mammals, as it is also observed in body areas covered with scales in other mammalian groups (e.g., in the tail of Mus musculus, Spearman and Hardy 1977; Alibardi 2004).

In the portions of the carapace formed by buckler osteoderms, an extremely thin layer of superficial dermis is always present underneath the epidermis. In neonates, as well as in late fetuses, of Dasypodinae (Vickaryous and Hall 2006; Krmpotic et al. 2012), the dermis is already j Dasypus novemcinctus, $\mathrm{H} \& \mathrm{E}$ stain. $\mathbf{k}$ D. hybridus, $\mathrm{H} \& \mathrm{E}$ stain. $\mathbf{I}$ D. novemcinctus, H\&E stain. $a$ artery, at adipose tissue, $g c$ gland cavity, $n$ nerves, $r b m$ red bone marrow, $v$ vein, $y b m$ yellow bone marrow

differentiated into two strata (superficial and deep), whereas in neonates of Euphractinae those strata are not yet differentiated. In fetuses and neonates of Dasypodinae, the osteoderms begin to form inside the superficial dermis (Vickaryous and Hall 2006; Krmpotic et al. 2012). In the adults, when the osteoderms are completely developed, both strata are incorporated into the osteoderm.

The histological structure of osteoderms of Euphractinae and Dasypodinae is similar. However, the type of articulation between them is different in each subfamily: syndesmoses with bone indentations in Euphractinae and syndesmoses with very small bone projections (only on the most superficial and deepest contacts) in Dasypodinae. In 

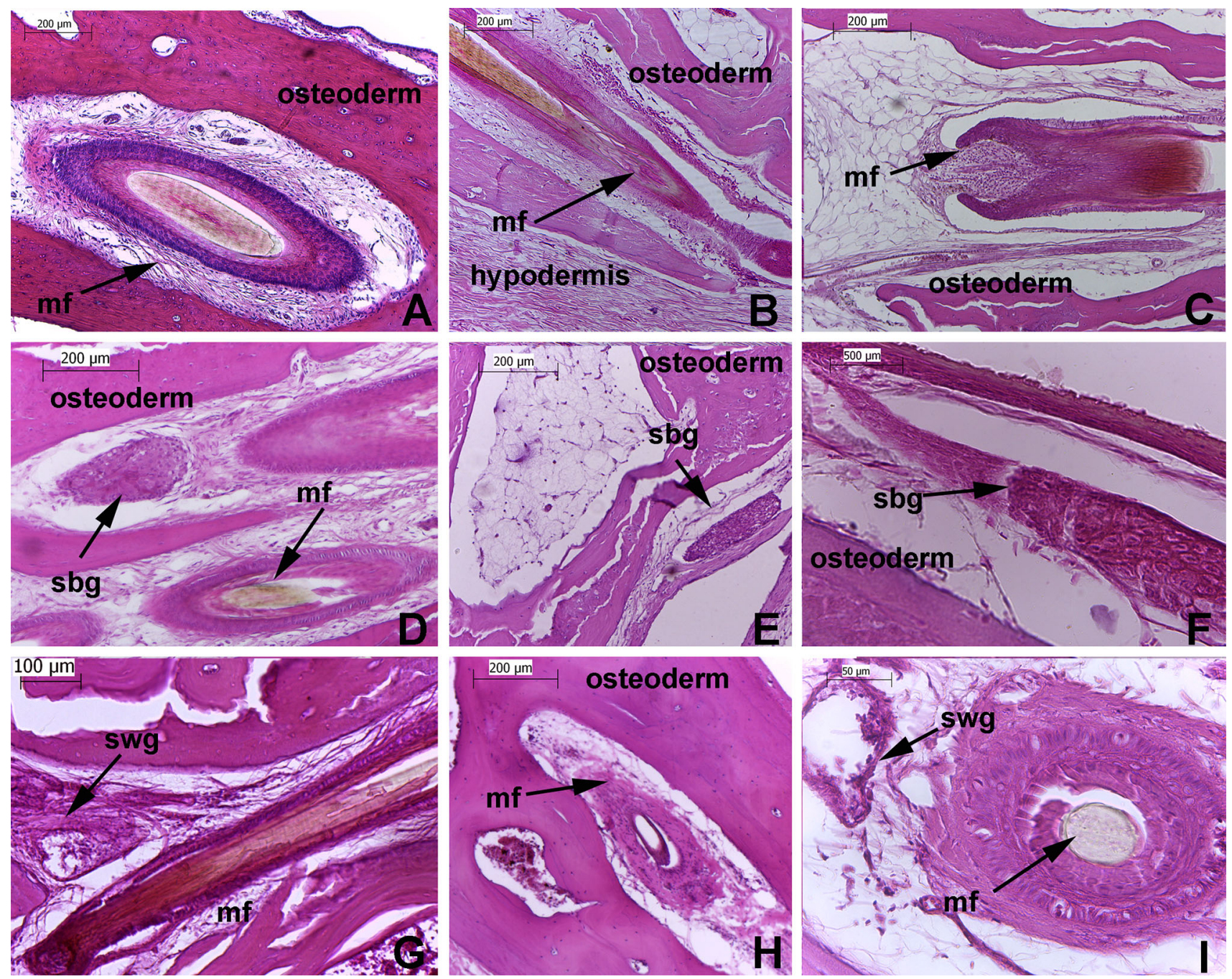

Fig. 12 Marginal piliferous follicles. a Chaetophractus vellerosus, H\&E stain. b Chaetophractus villosus, H\&E stain. c, d Euphractus sexcinctus, H\&E stain. e Zaedyus pichiy, H\&E stain. f C. villosus,
H\&E stain. g-h Dasypus hybridus, H\&E stain. i Dasypus novemcinctus, H\&E stain. $m f$ marginal piliferous follicle, sbg sebaceous gland, swg sweat gland

marrow is observed in the cavities of both portions of the movable osteoderms and in some cavities of the buckler osteoderms. Weiss and Wislocki (1956) suggested that hematopoietic activity occurs inside the large cavities of the cranial portion of the movable osteoderms and considered that this activity has seasonal variations, becoming active in the spring and summer. According to the information available in the collection catalogue, the specimen of the $D$. hybridus analyzed in this work was collected during the spring, whereas the specimen of D. novemcinctus was collected during the fall. Thus, the absence of red bone marrow in the latter could be related to this seasonal variation, and the difference in the relative production of blood cells in $D$. hybridus could represent interspecific variations. On the other hand, in Euphractinae this tissue was observed only in the osteoderms of the cephalic shield of $C$. villosus, as well as in osteoderms of the pelvic buckler of $Z$. pichiy collected 


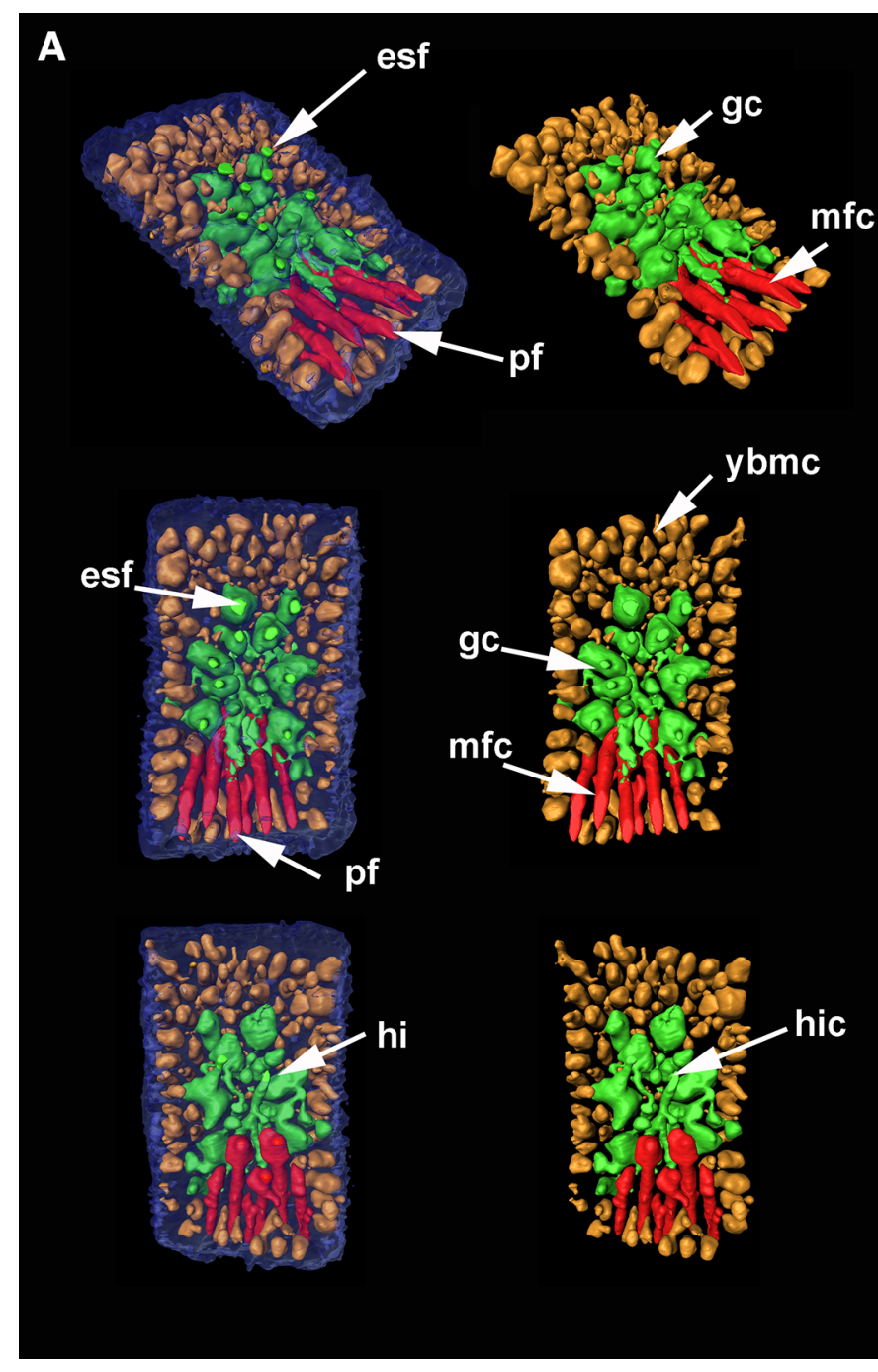

Fig. 13 3D reconstructions of buckler osteoderms. External contour of the osteoderms in blue. a Chaetophractus villosus. Top oblique views. Middle external side views. Bottom internal side views. b Dasypus hybridus. Top oblique views. Middle external side views. Bottom internal side views. esf external surface foramina, $g c$

during the spring. Red bone marrow was not identified in the specimens of $C$. vellerosus, even though they were collected during the spring (the collection date of E. sexcinctus was not available).

Some features possibly linked to environmental factors are also observed in early stages. Osteoderm development in the neonates of Dasypodinae starts earlier than in Euphractinae (Krmpotic et al. 2012). Conversely, the piliferous follicles and glands are relatively more developed in the Euphractinae at birth, a fact that is probably related to the environmental conditions where these taxa occur (Krmpotic et al. 2012).

The sebaceous glands in the large cavities of the buckler osteoderms and the caudal portion of the movable osteoderms are more developed in Euphractinae than in

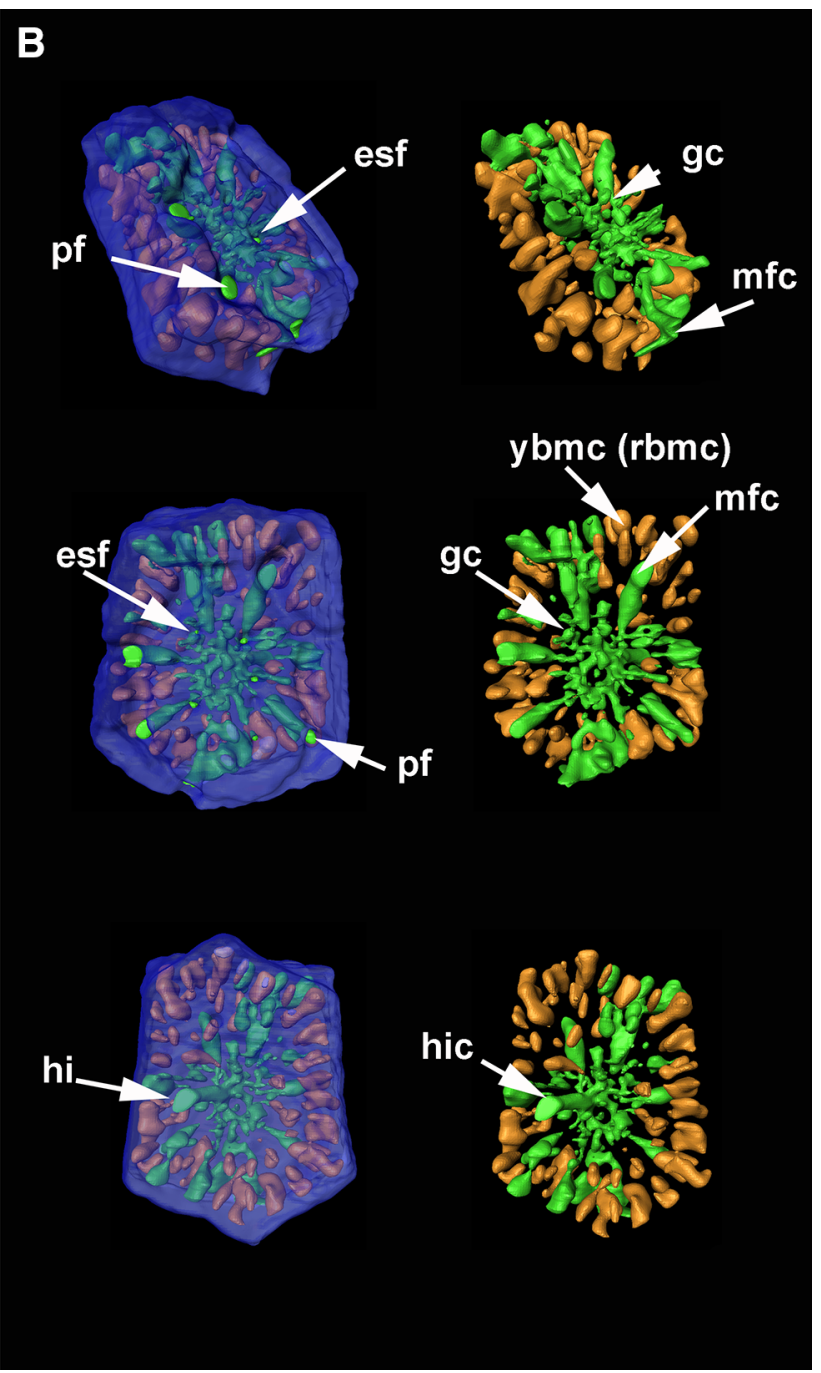

glandular cavity, $m f c$ marginal piliferous follicle cavity, $p f$ piliferous follicle foramina, $h i$ hypodermis ingression, hic hypodermis ingression cavity, $r b m c$ red bone marrow cavity, $y b m c$ yellow bone marrow cavity

Dasypodinae. In the former, these glands occupy approximately half of a cavity, whereas in Dasypodinae they are much smaller and formed by two lobes restricted to the narrow portion of each cavity that is continuous with the duct that opens onto the external surface foramina. In all the specimens under study, both glandular types (sebaceous and sweat glands) are associated with surface piliferous follicles of hairs that emerge through an external surface foramen. Chaetophractus villosus is the only species in which adults lack surface piliferous follicles, although Fernández (1931) suggested their presence in embryos and fetuses. The glands associated with those surface follicles are much more developed in neonates of Euphractinae than in those of Dasypodinae (Krmpotic et al. 2012), while the latter present a greater development of other integumentary 
structures (e.g., dermis, osteoderms). Finally, the marginal follicles of the Euphractinae were always associated with sebaceous glands only. In the Dasypodinae these follicles were generally associated with sweat glands only.

\section{Biogeographic distribution and morphological distinctiveness}

The geographic distribution of armadillos is closely related to the climatic-environmental conditions of the different regions, and this is shown in the differential distribution of the more diverse clades of extant Dasypodidae (Dasypodinae and Euphractinae).

The first group of armadillos (Dasypodinae), which represent the most basal cingulates, have always been related to warm and humid climates. It includes the Astegotheriini, the oldest xenarthrans known. The earliest records of this group (in the early Eocene) were in low latitudes in South America (Itaboraí, Brazil); however, their largest well-known diversity was retrieved in the high latitudes of Patagonia, Argentina (middle-late Eocene). In that moment, the early Eocene Climatic Optimum (EECO) produced a temperature and humidity much higher than today (Carlini et al. 2010).

Toward the Eocene-Oligocene transition (EOT), the Astegotheriini Vizcaíno (1994) diversity decreased, coinciding with the overall decline in marine temperatures, which strongly affected the peninsular continental areas such as southern South America. During this time lapse, but conversely, the Euphractinae appear and reach a remarkable diversity, and since the EOT they are established as the most varied group of armadillos in high latitudes (Carlini et al. 2009, 2010). Finally, since the EOT the Dasypodinae Astegotheriini have not been recorded in southern South America, except for a single species during the late Oligocene warming. However, they are found in low latitudes until the middle-late Miocene (Colombia and Ecuador) and coexisted with the first Dasypodinae Dasypodini (Carlini et al. 1997, 2014).

At present, some species mentioned in this work show a more northern distribution than others, having its southern limit in the center-north of Argentina (e.g., Dasypus novemcinctus, D. hybridus, Euphractus sexcinctus, Chaetophractus vellerosus), while other species (e.g., Zaedyus pichyi and Chaetophractus villosus) show a distribution from the center-north of Argentina to the austral continental limit.

According to McNab (1980), the areas of distribution of Dasypodidae would be closely related to the limitations established by their low body temperatures, low basal rates of metabolism, high minimal thermal conductance, and body size.
Among the Dasypodinae Dasypodini, D. novemcinctus ranges from the south of the USA to northern Argentina, approximately between the latitudes $40^{\circ} \mathrm{N}$ and $35^{\circ} \mathrm{S}$ (Wetzel 1985). Apparently, the distribution of the species is limited by the daily minimal temperature and the duration of the cold period, as well as by the amount of precipitation (given that it is not recorded in areas with less than $380 \mathrm{~mm}$ annual precipitation), and more than 24 frost days (McNab 1980; Taulman and Robbins 1996). In turn, Dasypus hybridus is distributed in the south of Paraguay and Brazil, all Uruguay, and eastern Argentina, up to $40^{\circ} \mathrm{S}$ approximately, occupying mostly open grasslands with moist soils and high terrain (Abba et al. 2011 and references therein). The Euphractinae Euphractini reach higher latitudes (up to $58^{\circ} \mathrm{S}$ ), and dryer environmental conditions do not seem to be a restriction for its areal distribution. Euphractus sexcinctus apparently prefers semi-arid environments (Schaller 1983). Chaetophractus vellerosus is distributed in southeast Bolivia, northwest Paraguay, and central Argentina, occupying arid regions with loose and sandy soil, and semiarid conditions (Cabrera 1957; Carlini and Vizcaíno 1987; Greegor 1985; Wetzel 1985; Soibelzon et al. 2006; Abba et al. 2007; Abba and Cassini 2010). Zaedyus pichiy and C. villosus are the species with the southernmost distributions. Zaedyus pichiy reach the south of Santa Cruz, Argentina, and have several adaptations to cold and dry habitats (Wetzel et al. 1985; Eisenberg and Redford 1992; McNab 1980; Superina and Abba 2014). Chaetophractus villosus is the extant euphractine with the widest distribution, ranging from the north and central portions of Argentina up to Tierra del Fuego Island, where they were recently introduced (Poljak et al. 2007).

In a general context, Dasypodinae are limited to humid tropical and subtropical zones, whereas the Euphractinae reach higher austral latitudes and xeric conditions (Wetzel et al. 2007; Aguiar and Fonseca 2008).

Our present work shows that the distinctive structural and morphological patterns of the osteoderms that compose the carapace in these two large groups (Dasypodinae and Euphractinae) have a remarkable taxonomic correlation, which can be related to the distribution of the species.

Therefore, the Dasypodinae mostly have a poor hair development (except for Cryptophractus pilosus, a species located in very high areas in the Peruvian Andes, see Castro et al. 2015), while Euphractinae have a greater hair development and large deposits of adipose tissue, which could provide a greater thermal insulation and reduction in the thermal conductance. In turn, the greater glandular development in Euphractinae could be associated with more arid and harsher environments with drier and sandier soils, which would involve a greater necessity of substances to maintain the ectodermic structures moist. 


\section{Conclusions}

To sum up, although the general conformation of osteoderms is similar in all the species analyzed, remarkable differences exist between both subfamilies:

1. The greater mobility of the carapace of Dasypodinae is related to the syndesmoses between osteoderms, which present minute bone projections (only on the most superficial), and also probably to the accessory "joints" inside each movable osteoderm (e.g., Dasypus hybridus). On the other hand, the carapace of Euphractinae is more rigid, with syndesmotic joints between osteoderms that have bone indentations along the entire thickness of the contact zone; although in $C$. vellerosus there is an accessory "joint" inside the osteoderm, it is restricted to its anterior-most portion.

2. The Euphractinae present more numerous and larger cavities filled with adipose tissue (yellow bone marrow) in the middle portion of the osteoderms, as well as more marginal follicles than the Dasypodinae.

3. Glandular cavities occupied by the surface follicles are more developed in Euphractinae. The sebaceous glands associated with surface follicles of hairs that emerge on the external surface are much more developed in the Euphractinae. Although these hairs are not always present in postnatal stages, the large sebaceous glands, which discharge on the surface, remain conspicuous.

4. The cavities occupied by marginal follicles of Euphractinae are more developed and have a tubular morphology. The marginal follicles in Dasypodinae are generally associated with sweat glands (and occasionally with sebaceous glands), whereas in Euphractinae they are associated only with sebaceous glands.

5. The production of blood cells inside the dorsal carapace is higher in Dasypodinae and could have seasonal variations (as well as specific variations).

6. The greater development of sebaceous glands in Euphractinae than in Dasypodinae could be related to preventing desiccation of the cornified scales in extremely arid climates. The greater number of marginal piliferous follicles and of large cavities filled with adipose tissue in the Euphractinae could also be related to the colder climates of areas that they may inhabit, as they provide thermal insulation.

\footnotetext{
Acknowledgments We thank Rubén Mario for his helpful contribution to the preparation of the sectioned material. Robert V. Hill and an anonymous reviewer greatly improved the original manuscript through their critical evaluation. We thank María Bernarda Epele for her help in the microCT acquisition. This work was supported by the
}

Consejo Nacional de Investigaciones Científicas y Técnicas in Argentina PIP CONICET 00806 and PICT 2013-2633 (to M.R.C.).

\section{References}

Abba AM, Cassini MH (2010) Ecological differences between two sympatric species of armadillos (Xenarthra, Mammalia) in a temperate region of Argentina. Acta Theriol 55:35-44

Abba AM, Cassini MH, Vizcaíno SF (2007) Effects of land use on the distribution of three species of armadillos (Mammalia, Dasypodidae) in the Pampas, Argentina. J Mammal 88(2):502-507

Abba AM, Cassini MH, Galliari FC (2011) Nuevos aportes a la historia natural de la mulita pampeana Dasypus hybridus (Mammalia, Dasypodidae). Iheringia Sér Zool 101(4):325-335

Aguiar JM, Fonseca GD (2008) Conservation status of the Xenarthra. In: Vizcaíno SF, Loughry WJ (eds) The biology of the Xenarthra. University Press of Florida, Gainesville, pp 215-231

Alibardi L (2004) Dermo-epidermal interactions in reptilian scales: speculations on the evolution of scales, feathers, and hairs. J Exp Zool B Mol Dev Evol 302(4):365-383

Cabrera A (1957) Catálogo de los mamíferos de América del Sur. Rev Mus Argent Cienc Nat Bernard Rivadavia 4(1):1-307

Carlini AA, Vizcaíno SF (1987) A new record of the armadillo Chaetophractus vellerosus (Gray, 1865) (Mammalia, Dasypodidae) in the Buenos Aires Province of Argentina: possible causes for the disjunct distribution. Stud Neotrop Fauna Environ 22(1):53-56

Carlini AA, Vizcaíno SF, Scillato-Yané GJ (1997) Armored xenarthrans: a unique taxonomic and ecologic assemblage. In: Kay RF, Madden RH, Cifelli RL, Flynn JJ (eds) Vertebrate palaeontology in the neotropics: the Miocene Fauna of La Venta, Colombia. Smithson Inst Press, Washington, DC, pp 213-226

Carlini AA, Ciancio MR, Flynn JJ, Scillato-Yané GJ, Wyss AR (2009) The phylogenetic and biostratigraphic significance of new armadillos (Mammalia, Xenarthra, Dasypodidae, Euphractinae) from the Tinguirirican (Early Oligocene) of Chile. J Syst Palaeontol 7(4):489-503

Carlini AA, Ciancio MR, Scillato-Yané GJ (2010) Middle Eoceneearly Miocene Dasypodidae (Xenarthra) of southern South America: faunal succession at Gran Barranca-biostratigraphy and palaeoecology. In: Madden RH, Carlini AA, Vucetich MG, Kay RF (eds) The paleontology of Gran Barranca: evolution and environmental change through the Middle Cenozoic of Patagonia. Cambridge University Press, Cambridge, pp 106-129

Carlini AA, Castro MC, Madden RH, Scillato-Yané GJ (2014) A new species of Dasypodidae (Xenarthra: Cingulata) from the late Miocene of northwestern South America: implications in the Dasypodini phylogeny and diversity. Hist Biol 26(6):728-736

Castro MC, Ciancio MR, Pacheco V, Salas-Gismondi RM, Bostelmann JE, Carlini AA (2015) Reassessment of the hairy longnosed armadillo "Dasypus" pilosus (Xenarthra, Dasypodidae) and revalidation of the genus Cryptophractus Fitzinger, 1856. Zootaxa 3947(1):30-48

Ciancio MR, Carlini AA (2008) Identificación de ejemplares tipo de Dasypodidae (Mammalia, Xenarthra) del Paleógeno de Argentina. Rev Mus Argent Cienc Nat 10(2):221-237

Ciancio MR, Krmpotic CM, Carlini AA, Barbeito CG (2007) Morfología interna de los osteodermos Dasypodinae y Eupractinae (Xenarthra, Dasypodidae). Actas III Congreso de Mastozoología de Bolivia, Libro de Resúmenes, p 50

Ciancio MR, Carlini AA, Campbell KE, Scillato-Yané GJ (2013) New palaeogene cingulates (Mammalia, Xenarthra) from Santa Rosa, Perú and their importance in the context of South American faunas. J Syst Palaeontol 11(6):727-741 
Eisenberg JF, Redford KH (1992) Mammals of the Neotropics, Volume 2: The Southern Cone: Chile, Argentina, Uruguay, Paraguay, vol 2. University of Chicago Press, Chicago

Fernández M (1931) Sobre la anatomía microscópica y embriología de la coraza de Dasypus villosus. In: Actas de la Academia Nacional de Ciencias de la Rep. Argentina X, pp 61-121

Greegor DH (1985) Ecology of the little hairy armadillo Chaetophractus vellerosus. In: Montgomery GG (ed) The evolution and ecology of armadillos, sloths and vermilinguas. Smithsonian Institution Press, Washington, pp 397-405

Hill RV (2006) Comparative anatomy and histology of xenarthran osteoderms. J Morphol 267:1441-1460

Krmpotic CM, Ciancio MR, Barbeito CG, Mario RC, Carlini AA (2009) Osteoderm morphology in recent and fossil euphractinae xenarthrans. Acta Zool 90:339-351

Krmpotic CM, Galliari FC, Barbeito CG, Carlini AA (2012) Development of the integument of Dasypus hybridus and Chaetophractus vellerosus, and asynchronous events with respect to the postcranium. Mamm Biol 77(5):314-326

Krmpotic CM, Carlini AA, Galliari FC, Favaron P, Miglino MA, Scarano AC, Barbeito CG (2014) Ontogenetic variation in the stratum granulosum of the epidermis of Chaetophractus vellerosus (Xenarthra, Dasypodidae) in relation to the development of cornified scales. Zoology 117:392-397

McNab BK (1980) Energetics and the limits to a temperate distribution in armadillos. J Mammal 61(4):606-627

Moss ML (1969) Comparative histology of dermal sclerifications in reptiles. Cells Tissues Organs 73(4):510-533

Poljak S, Escobar J, Deferrari G, Lizarralde M (2007) Un nuevo mamífero introducido en la Tierra del Fuego: el" peludo" Chaetophractus villosus (Mammalia, Dasypodidae) en Isla Grande. Rev Chil Hist Nat 80(3):285-294

Schaller GB (1983) Mammals and their biomass on a Brazilian ranch. Arq Zool 31:1-36

Scillato-Yané, GJ (1982) Los Dasypodidae (Mammalia, Edentata) del Plioceno y Pleistoceno de Argentina. In: Tesis Doctoral (inédita), Facultad de Ciencias Naturales y Museo, UNLP

Sire JY, Donoghue PC, Vickaryous MK (2009) Origin and evolution of the integumentary skeleton in non tetrapod vertebrates. J Anat 214(4):409-440
Soibelzon E, Carlini AA, Tonni EP, Soibelzon HL (2006) Chaetophractus vellerosus (Mammalia: Dasypodidae) in the Ensenadan (Early-Middle Pleistocene) of the southeastern Pampean region (Argentina). Paleozoogeographical and paleoclimatic aspects. N Jahrb Geol Paläontol Mon 12:734-748

Spearman RIC (1966) The keratinization of epidermal scales, feathers and hairs. Biol Rev 41:56-96

Spearman RIC, Hardy JA (1977) Ultrastructure of the contrasting types of keratinization seen in the tail epidermis of the laboratory mouse Mus musculus. Arch Dermatol Res 258:33-40

Superina M, Abba AM (2014) Zaedyus pichiy (Cingulata: Dasypodidae). Mamm Species 46(905):1-10

Taulman JF, Robbins LW (1996) Recent range expansion and distributional limits of the nine banded armadillo (Dasypus novemcinctus) in the United States. J Biogeogr 23(5):635-648

Vickaryous MK, Hall BK (2006) Osteoderm morphology and development in the nine banded armadillo, Dasypus novemcinctus (Mammalia, Xenarthra, Cingulata). J Morphol 267(11):1273-1283

Vickaryous MK, Sire JY (2009) The integumentary skeleton of tetrapods: origin, evolution, and development. J Anat 214(4):441-464

Vizcaíno SF (1994) Sistemática y Anatomía de los Astegotheriini Ameghino, 1906 (nuevo rango) (Dasypodidae, Dasypodinae). Ameghiniana 31:3-13

Weiss LP, Wislocki GB (1956) Seasonal variations in hematopoiesis in the dermal bones of the nine banded armadillo. Anat Rec 126(2):143-163

Wetzel RM (1985) The identification and distribution of recent Xenarthra (=Edentata). In: Montgomery GG (ed) The evolution and ecology of armadillos, sloths, and vermilinguas. Smithson Inst Press, Washington, DC, pp 5-21

Wetzel RM, Gardner AL, Redford KH, Eisenberg JF (2007) Order Cingulata Illiger, 1811. In: Gardner AL (ed) Mammals of South America. Marsupials, Xenarthrans, Shrews, and Bats. University of Chicago Press, Chicago, pp 128-157

Wolf D, Kalthoff DC, Sander PM (2012) Osteoderm histology of the Pampatheriidae (Cingulata, Xenarthra, Mammalia): implications for systematics, osteoderm growth, and biomechanical adaptation. J Morphol 273(4):388-404 